\title{
An Investigation Of Dynamic Dividend Behavior In Korea
}

\author{
Jinho Jeong, Korea University, Korea
}

\begin{abstract}
The principal objective of this study was to assess the dynamic dividend behavior of firms in Korea. Specifically, this study tests the presence of dividend smoothing and identifies the firmlevel factors influencing the degree of dividend smoothing. For this purpose, 299 firms listed on the Korea Stock Exchange over a 26-year period, from 1981 to 2006, were investigated.

The empirical results of this study demonstrate that Korean firms made dividend payments which were quite closely related to the average interest rate over the sample period. A change in dividend payments is less likely to reflect a change in the fundamentals of Korean companies. Instead, it appears to be related significantly to movements in the interest rate. This study also finds that the majority of Korean firms pay smoothed dividends. However, the degree of dividend smoothing in Korean firms was determined to be lower than that observed in US firms. In addition, the results demonstrate that the long-term target payout ratio is significantly lower than the observed payout ratio. The results indicate that Lintner's dividend smoothing model does not explain the dynamic dividend behavior in Korea.
\end{abstract}

The theoretical determinants of dividend smoothing were assessed by regressing the degree of dividend smoothing of firms against the firm characteristics. The results show that riskier firms tend to pay more smoothed dividends, thus supporting the prediction previously made by Kumar (1988). However, contrary to the theoretical predictions, our results find that larger and older firms are more likely to smooth dividends in Korea. Controlling shareholder's ownership, growth, and financial slack all appear to exert insignificant effects on the degree of dividend smoothing. The results suggest that the information and agency theories of dividend smoothing do not explain the dynamic dividend policy of Korean firms.

Keywords: dividend; dynamic policy; dividend smoothing; Lintner model

\section{INTRODUCTION}

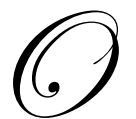

ne of the best-known dividend behaviors is the smoothing of firm's dividends relative to earnings. In his seminal paper, Lintner (1956) found that firms in the US smoothly adjust their dividends to maintain a target long-run payout ratio. Lintner's finding of dividend smoothing has been confirmed by a number of studies since its publication. Whereas dividend smoothing is a well-established empirical fact, the empirical evidence is based principally on information collected in the US market. The dividend policies of corporations differ significantly across countries due to a variety of institutional and financial market differences. ${ }^{1}$

The principal objective of this study was to assess the dividend policies of firms in Korea. In particular, this study attempted to determine whether Korean firms follow stable dividend policies, as in developed markets in which dividend smoothing is a stylized fact. This paper also identifies the firm-level factors influencing the degree of dividend smoothing. The paper highlights the importance of institutional features to dividend policy and points to

\footnotetext{
${ }^{1}$ Aivazian (2003) finds that empirical dividend policy equations of emerging market firms are structurally different from those of US firms .
} 
the advantages of studying dividend policies in different institutional environments. The results of this study provide useful insight into the role of institutional factors in deciding dynamic dividend policy at the firm level.

Korea presents several interesting features with regard to the examination of dynamic dividend policy. Firstly, Korea is one of the most successful and most rapidly growing economies in the world. The economic growth and transformation of the Korean economy has been noted previously by various researchers. ${ }^{2}$ From a povertystricken and economically backward country in 1962 with a GDP per capita of only US\$82, Korea has grown into the world's 12 th largest economy and one of the world's top 10 exporters in $2007 .^{3}$ This rapid economic growth may have had significant effects on the dynamic dividend policies of Korean firms. A great deal of empirical research has shown that firms tend to pay stable dividends during periods of high growth. Thus, it will be interesting to determine how firms set their dynamic dividend policy in a rapidly growing economy such as Korea.

Secondly, the Korean ownership structure is frequently characterized by the dominance of one primary owner who manages a sizeable number of affiliated companies with just a small amount of shares. Through a unique ownership structure, referred to generally as circular cross-investment (i.e., a pyramid ownership control structure coupled to cross-shareholding among subsidiaries), the owner is capable of exercising ownership rights to control many companies in different industries. Consequently, there is a possibility of an agency problem in which controlling shareholders expropriate value from minority shareholders and thus influence dividend policy.

Thirdly, there is no capital gain tax on listed stocks in Korea, while a tax of $15.4 \%$ is applied to the dividend income. ${ }^{4}$ Several papers relate dividend signaling to the taxation disadvantage. It has been well established that dividends can be utilized as a credible signal for the value of a firm due to the tax disadvantage of dividend payments (Bhattacharya, 1979; John and Williams, 1985; and Bernheim, 1991). This tax-based explanation indicates that Korean firms may exhibit somewhat different dynamic dividend patterns, as unfavorable tax treatments of dividend income are more serious than the developed countries like the United States. ${ }^{5}$

Fourthly, unlike US stocks, Korean stocks have a face value which performs an important role in deciding a firm's dividend policy. The Capital Market Promotion Acts of 1968 made it mandatory for listed corporations to pay annual dividends divided by the face value at a level equal to the interest rate on one-year time deposits. ${ }^{6}$ Although this policy is not enforced, it has been generally understood that the interest rate is a crucial consideration in deciding the level of dividend payments in Korea. In this case, changes in the annual dividend payments may merely be related to changes in the interest rates rather than reflecting the fundamentals of companies.

This study contributes to the relatively limited literature regarding the determinants of dynamic dividend behavior in Korea. The diversity of dividend policies selected by firms appears to indicate that the dividend smoothing decision is considerably more important for some firms than for others. The existing dividend smoothing literature is extensive and well-known, yet few empirical investigations have been conducted into the crucial issue as to why differences exist in dividend smoothing patterns amongst firms. In this paper, we explore the manner in which dividend smoothing differs across firms and empirically examine the factors that help to explain measured differences in the extent to which firms smooth their dividends. A number of firm-specific factors are relevant to signalling and agency explanations of dividend smoothing, thus implying that the absence of these factors in some firms, and their clear presence in others, could empirically explain cross-sectional differences in firms' dividend smoothing behavior. Empirical studies of dividend behavior tend to support the dividend smoothing theory, but have not focused on this paper's goal; namely, the use of a theoretical hypothesis concerning firm-specific factors to

\footnotetext{
${ }^{2}$ See Harvie and Lee (2002).

${ }^{3}$ Wikipedia, 2008.

${ }^{4}$ This is for most investors who own less than 3 percent of total shares or market value of less than 10 billion won. As for majority (controlling) shareholders, if stocks are held for less than one year, a 30 percent capital gains tax rate is levied; otherwise, 20 percent is applied.

${ }^{5}$ In US, the Jobs and Growth Tax Relief Reconciliation Act of 2003 has diminished the taxation difference between capital gains and dividends.

${ }^{6}$ This custom exists until 2003 when KRX mandates firms to announce dividend payment based on the market value by changing its corporate information disclosure system. For exchange listed firms, face value of stock is usually 5,000 KRW. For KOSDAQ listed firms, face value of stock is usually $500 \mathrm{KRW}$. In most cases, market price is significantly different from face value.
} 
explain cross-sectional differences in firms' dividend smoothing behavior. It should be noted that this is the first paper to utilize the factors critical to agency cost and signalling theory models in an effort to empirically explain differences in Korean firms' dividend smoothing behavior.

The empirical results of this study demonstrate that the majority of Korean firms pay smoothed dividends. However, the speed of adjustment to the target payout ratio for Korean firms is faster than that of US firms. These results imply that Korean firms pay less smoothed dividends than US firms. Theoretical models of dividends based on company risk, size, and growth factors perform important functions in the empirical explanation of the crosssection of dividend smoothing behavior, but a different relationship between these explanatory variables and the degree of dividend smoothing exists between US and Korean firms. The results of our study show that riskier firms tend to pay more smoothed dividends, thus supporting the prediction previously made by Kumar (1988). However, contrary to the theoretical predictions, our results demonstrate that larger and older firms are more likely to smooth dividends in Korea.

Section II discusses studies related to this research. Section III introduces Lintner's measures of dividend smoothing. Theoretical considerations that might influence dividend smoothing decisions are then introduced in order to explain differences in firms' dividend smoothing choices. Section IV provides the cross-sectional test results for differences in firms' dividend smoothing behavior. Section V provides our concluding remarks.

\section{RELATED STUDIES}

The dividend smoothing literature has its roots in the research of Lintner (1956). Numerous subsequent studies have demonstrated the presence of dividend smoothing at both the individual firm and aggregate levels (Fama and Babiak (1968), Laub (1976), Lee, Djarraya and Wu (1987), Marsh and Merton (1987), Garrett and Priestley (2000), Kumar and Lee (2001), Allen and Michaely (2003), and Brav et al. (2005)). Several studies have attempted to formulate an explanation as to why firms pay smoothed dividends. John and William's (1985) signalling explanation of dividend smoothing constituted an important theoretical development in the dividend smoothing hypothesis. They showed that, in equilibrium, the optimal dividend policy was to pay smoothed dividends relative to stock prices. Their model implies that a higher degree of information asymmetry results in a higher degree of dividend smoothing. Kumar (1988) also developed a signaling model to explain the dividend smoothing. In Kumar's (1988) model, there is a partial pooling of various firm types, and no separating equilibria exist. There is an equilibrium set of ranges of firm value and insiders who can credibly announce the exclusive ranges of the firm's true value via specific dividend payments. In Kumar's signaling equilibrium, a unique level of dividends is associated with each distinct range of firm values. A firm announcing a level of dividends that deviates from a certain range is regarded by the market as having a value in the lowest range. Unlike the dividend smoothing concepts propounded by John and Williams (1985), Kumar's dividend smoothing is characterized by a step function of earnings, thereby indicating that dividends are a discrete process. Using comparative statistics, he predicted that risky firms would tend to smooth dividends more profoundly. Rozycki (1997) demonstrated that the personal income tax provided managers with a motivation to smooth dividend payments. He determined that dividend smoothing had increased the wealth for a tax-paying investor by reducing the present value of the investor's future expected income tax liabilities. He also demonstrated that smoothing the dividend stream was more important to firms with volatile earnings. Michaely and Roberts (2006) conjectured that ownership structure might play a crucial role in dividend smoothing. According to the study, firms with a higher level of large shareholder ownership are less likely to smooth dividends relative to earnings, as they are less related to agency issues and asymmetric information. $^{7}$

\footnotetext{
${ }^{7}$ Empirical evidence suggests that management's reluctance to cut dividends is partly driven by investors' reactions to such announcements (i.e., Michaely, Thaler and Womack (1995), Grullon, Michaely, and Swaminathan (2002)). In addition, Brav et al. (2005) report that firms with high owner's concentration are more likely to pay dividends in response to temporary changes in earnings.
} 


\section{DTERMINANTS OF DIVIDEND SMOOTHING}

This paper employs factors that are either directly or indirectly suggested by previous studies and institutional features in order to explain differences in firms' dividend smoothing behavior.

\section{Measures Of Dividend Smoothing}

We measured the degree of dividend smoothing using Lintner's partial adjustment model. Lintner (1956) modelled the change in corporation i's time t dividend per share, $\Delta D_{i, t}$, as varying proportionately with a speed of adjustment factor $c_{i}$ times the amount by which last period's dividend is exceeded by the current desired payout (the desired payout ratio $r_{i}$ times earnings per share $E P S_{i, t}$ ):

$$
\Delta D_{i, t}=a_{i}+c_{i}\left(r_{i} E P S_{i, t}-D_{i, t-1}\right)+u_{i, t}
$$

Or

$$
\Delta D_{i, t}=a_{i}+b_{i, 1} E P S_{i, t}+b_{i, 2} D_{i, t-1}+u_{i, t}
$$

where $a_{i}$ is a constant, $u_{i, t}$ is a normally distributed random error term, $b_{i, 1}=c_{i} r_{i}$, and $b_{i, 2}=-c_{i}$. Lintner (1956) tested a rearranged version of equation (1) on a sample of 26 firms using annual data for the time period from 1918 to 1941, and found that the model explained $85 \%$ of the variation in dividends. He also showed that the speed of adjustment averaged $30 \%$ per year, and the target payout ratio averaged $50 \%$ of earnings. Using a similar model, Fama and Babiak (1968) examined data for two samples of 201 and 191 U.S. firms over the period of 1947 to 1964. Their results revealed a slightly higher speed of adjustment, of $36.6 \%$. The Lintner model of dividend smoothing is still widely regarded as the standard model for dividend policy. A speed of adjustment parameter, $c_{i}$, close to 1 indicates no proportionate smoothing of dividends relative to percentage changes in earnings, whereas the very low speed of adjustment parameter values indicates that dividends move independently of earnings.

\section{Firm Characteristics And Dividend Smoothing}

Theory suggests a number of factors that are potentially relevant to empirical explanations of measured differences in dividend smoothing behavior.

\section{Information Environment}

Dividend signaling theory indicates that in the presence of asymmetric information, a firm's dividend policy can help to credibly convey information held by insiders concerning the firm's future prospects. The model constructed by John and Williams (1985) suggests that a firm's information environment is related to the extent to which dividends are smoothed relative to earnings. Freeman (1987) and Kross and Schroeder (1988) reported that the market prices of large firms reflected earnings more accurately than those of small firms. Thus, it is possible that smaller firms may have a greater proclivity to use dividends as a signal of value. In fact, Eddy and Seifert (1988) reported that the information content of a dividend change was greater for smaller firms than for large firms. Ghosh and Woolridge (1988) and Dewenter and Warther (1998) demonstrated that the market reaction to dividend changes was a function of the degree of information asymmetry. All of these considerations imply that size is likely to reduce signaling needs and, consequently, the degree of dividend smoothing.

\section{Risk}

Kumar (1988) has predicted that firms in riskier industries are also more likely to smooth dividends in order to develop a reputation for having low systematic risk. The results from earnings volatilities studies have emphasized the relationship between risk and the incentive to smooth dividends, as high earning volatilities have been shown to be associated with lower than expected future profitability and future stock returns (Ronen and Sadan 
(1981), Chaney and Lewis (1995), and Billings (1999)). High risk companies would have a greater incentive to smooth dividends.

\section{Growth}

Signaling theory implies that firms with growth opportunities are more likely to pay dividends to convey this information to the market. At the same time, these firms will also have a greater need to retain a higher proportion of earnings to support their valuable investment projects. This combination of requirements results in declining dividend payout ratios and smoothed dividends relative to earnings for firms with high growth rates. A further implication of this combination of requirements is that high growth firms are likely to be more sensitive to the tradeoff between dividend signaling needs and dividend signaling costs, whereas low growth firms will be much less sensitive to the tradeoff because they would not wish to use costly signals. Therefore, growth is expected to be negatively related to the degree of dividend smoothing, since the deviation from the smoothed dividend becomes a more expensive signal for high growth firms.

\section{Ownership Structure}

It is well known that a pattern of stable dividend payments can mitigate the agency costs of equity, while also signaling the consistent quality of the firm's earnings. Gomes (2000) and La Porta et al. (2000) have argued that this solution depends on the ownership structure of the firm. Stable dividends may be an optimal solution for a firm with a dispersed share ownership. However, closely held firms may not need to signal earnings quality and may not need to solve the agency problem. For instance, Dewenter and Warther (1998) applied the Lintner model to Japanese firms that were members of a Keiretsu, and reported that the Keiretsu firm paid dividends in a manner highly sensitive to corporate earnings. These findings suggest that ownership structure influences the need for dividends to reduce the agency problem and to provide managerial monitoring. For closely held firms, the immediate change in fundamental value is less visible and, thus, potentially less important for the dividend decision-making process. In fact, Brav et al. (2005) reported that closely held firms regarded the consequences of dividend cuts and omissions to be less serious. They demonstrated that closely held firms were more likely to pay dividends in response to temporary changes in earnings than were firms with diffused ownership. This discussion suggests that firms with diffused ownership will be likely to smooth their dividends more than is the case with closely held firms.

\section{Financial Slack}

Financial slack can also be considered to be a potentially important factor in the decision to smooth dividends. The presence of financial slack will, in theory, reduce external financing requirements and thus solve the "underinvestment" problem, thereby reducing the signaling needs of firms and the incentive to smooth dividends (Myers \& Majluf (1984), and John \& Williams (1985)). Financial slack is expected to have an inverse relationship with the degree of dividend smoothing.

Theoretical explanations of differences in firms' dividend smoothing measures were assessed in this study using the following cross-sectional regression model:

$$
\mathrm{C}_{\mathrm{i}}=\beta_{0}+\beta_{1} \text { SIZE }+\beta_{2} \text { LARGE }+\beta_{3} \text { HISTORY }+\beta_{4} \text { SLACK }+\beta_{5} \text { EV }++\beta_{6} \text { GROWTH }
$$

where firm size (SIZE) is estimated by the natural logarithm of total assets, growth (GROWTH) is measured by the growth rate in size over at least a 15-year period, financial slack (SLACK) is the ratio of accumulated retained earnings to total assets, and earnings variability (RISK) is assessed using the standard deviation of earnings per share over at least a 15-year period. Listing years (HISTORY) is measured by the number of years listed during the sample period. The percentage of the stock held by the largest shareholders (OWN) is used as a proxy for the concentration of controlling shareholders. Degree of dividend smoothing (DDS) is measured by the speed of adjustment, $C_{i}$, in equation (1). The theory implies the following coefficient signs: $\beta_{1}, \beta_{2}, \beta_{3} \& \beta_{4}>0, \beta_{5}, \beta_{6}<0$. 


\section{EMPIRICAL RESULTS}

Equation (1) was fitted to a sample of firms listed on the Korea Stock Exchange over the 26-year period from 1981 to 2006 in order to estimate the measures of the degree of dividend smoothing of firms. The following sample selection criteria were employed:

1. Firms had to have at least 15 years of earnings and dividend data during the period 1980-2006, as reported in the Korea Listed Companies Association database.

2. When estimating Eq. (1), all firms with non-positive EPS or zero dividends were eliminated from the sample, in order to prevent the spurious results of dividend smoothing.

3. A further screen excluded firms with less than 15 observations for each firm characteristic variable used in the regression. From a total of 732 firms, 299 firms fulfilled these screening criteria.

The exclusion of firms with negative earnings and zero dividends has the advantage of eliminating "spurious dividend smoothing." This spurious dividend smoothing arises naturally, rather than being the result of the conscious management of dividend policy. Dividend smoothing implies a deliberate effort on the part of managers to adjust dividend payments in response to variations in the earnings stream.

Table 1 shows the descriptive statistics. From this table, the following remarks are found:

Table 1: Sample Statistics

\begin{tabular}{|l|c|c|c|c|}
\hline Variable* & Mean & Standard Deviation & Min & Max \\
\hline $\mathrm{C}_{\mathrm{i}}$ & 0.7033 & 0.2463 & 0.0870 & 1.4640 \\
\hline SIZE & 18.6855 & 1.1652 & 16.3413 & 24.2445 \\
\hline OWN & 30.0319 & 11.9095 & 6.5146 & 82.3063 \\
\hline SLACK & 0.1763 & 0.1099 & 0.0133 & 0.5811 \\
\hline RISK & 2.7466 & 4.1652 & 0.1472 & 44.4989 \\
\hline GROWTH & 0.1383 & 0.0985 & -0.0651 & 0.8482 \\
\hline Target payout ratio & 0.1813 & 0.1462 & 0.0010 & 0.9225 \\
\hline HISTORY & 18.9512 & 3.9915 & 13.0000 & 26.0000 \\
\hline DE & 0.4057 & 0.2750 & 0.0738 & 3.5506 \\
\hline EXP & 0.5191 & 0.2179 & 0.0556 & 0.9967 \\
\hline
\end{tabular}

* Firm size (SIZE) is estimated by the natural logarithm of total assets, growth rate (GROWTH) is the average growth rate of size over a minimum of 15 years prior to 2006 and a maximum of the twenty six years, financial slack (SLACK) is the ratio of accumulated retained earnings to total assets, and earnings variability (RISK) is measured using the standard deviation of earnings per share over a minimum of 15 years prior to 2006 and a maximum of the twenty-six years. Listing years (HISTORY) is measured by the number of years listed during the sample period. The percentage of the stock held by the largest shareholders $(\mathrm{OWN})$ is used as a proxy for the concentration of controlling shareholders. Dividend payout ratio (DE) is measured by dividends per share divided by earnings per share. $\mathrm{C}_{\mathrm{i}}$ is measured by the speed of adjustment in equation (1). EXP is the explanatory power of the Lintner model.

The average speed of adjustment is $68 \%$ and the target payout ratio is $18.3 \%$. The model explained $51 \%$ of the variation in dividends. As compared with the US results, the table demonstrates that dividend behavior in Korea is explained less well by the Lintner model, and dividends are more sensitive to changes in temporary earnings. For example, the one estimated by Lintner was approximately $30 \%$, with a target payout ratio of $50 \%$. Lintner's implicit target payout ratio appears to be substantially higher than ours. The estimations of the Lintner model for Korean firms indicate that dividend decisions are not predicated on the long-term target payouts, as was hypothesized originally by Lintner (1956). This view is supported by the lower target payout ratios, which deviate substantially from the observed payout ratios. With regard to average dividend payments, Korean firms paid $480 \mathrm{KRW}$ (or 0.48 USD) per share. ${ }^{8}$ The average dividend payout ratio is $40.5 \%$, which is lower than that of US firms. ${ }^{9}$ The lower

${ }_{9}^{8}$ Average dividend payout ratio is calculated by EPS*DE.

${ }^{9}$ Aivazian. (2003). 
observed payout ratio in Korea may be attributable to the different tax treatment of dividend income tax relative to the capital gains tax. Korean firms appear to have less incentive to pay dividends, as the unfavorable tax treatment of dividend income over capital gain is more serious than is the case in the US. ${ }^{10}$ In addition, many investors in Korea disregard dividends and consider stock price appreciation as the principal component of stock returns. Korean investor's attitude toward dividends seems to also contribute to lower dividend payout ratios.

It has been generally understood that the interest rate is a crucial consideration for deciding the level of dividend payments in Korea. To investigate this issue, we have compared the dividend yields (based on face value) with the deposit rates during the sample period. The average dividend payment is $10.9 \%$ of the face value, which is $2.3 \%$ higher than the average deposit rate during the sample period. However, Figure 1 and Table 2 demonstrate the existence of a systematic relationship between dividend payments and deposit rates. Table 2 shows that dividend yields are related positively to the average deposit interest rate from 1981 to 1995, during which time the rate was regulated by the government. ${ }^{11}$ As the deposit rate was liberalized, the dividend yield becomes negatively related with the deposit rate. The correlation coefficient between the dividend yield and the deposit rate was $68 \%$ during the period from 1981 to 1995, and then became $-89 \%$ during the period between 1996 and 2006. These results indicate that the deposit rate performs a crucial function in deciding dividend payments for Korean firms.

Table 2: The Relationship Between Deposit Rate And Dividend Payment Divided By Face Value

\begin{tabular}{|c|c|c|}
\hline Year & Dividend Payment/Face Value & Deposit Rate \\
\hline 1981 & 0.1771 & 0.162 \\
\hline 1982 & 0.1168 & 0.08 \\
\hline 1983 & 0.1208 & 0.08 \\
\hline 1984 & 0.1166 & 0.1 \\
\hline 1985 & 0.1233 & 0.1 \\
\hline 1986 & 0.1301 & 0.1 \\
\hline 1987 & 0.09477 & 0.1 \\
\hline 1988 & 0.10859 & 0.1 \\
\hline 1989 & 0.09655 & 0.1 \\
\hline 1990 & 0.10705 & 0.1 \\
\hline 1991 & 0.0868 & 0.1 \\
\hline 1992 & 0.08054 & 0.1 \\
\hline 1993 & 0.06854 & 0.085 \\
\hline 1994 & 0.07705 & 0.0925 \\
\hline 1995 & 0.08171 & 0.0875 \\
\hline 1996 & 0.05907 & 0.1079 \\
\hline 1997 & 0.05923 & 0.1132 \\
\hline 1998 & 0.05446 & 0.133 \\
\hline 1999 & 0.1017 & 0.069 \\
\hline 2000 & 0.11631 & 0.071 \\
\hline 2001 & 0.0871 & 0.0543 \\
\hline 2002 & 0.12163 & 0.0473 \\
\hline 2003 & 0.14036 & 0.0415 \\
\hline 2004 & 0.17843 & 0.0375 \\
\hline 2005 & 0.18239 & 0.0346 \\
\hline 2006 & 0.14595 & 0.045 \\
\hline Mean (1981-2006) & 0.1089 & 0.08620 \\
\hline Mean (1981-1995) & 0.10573 & 0.09913 \\
\hline Mean (1996-2006) & 0.0956 & 0.09146 \\
\hline Correlation (1981-2006) & -0.3901 & \\
\hline Correlation (1981-1995) & 0.68343 & \\
\hline Correlation (1996-2006) & -0.8907 & \\
\hline
\end{tabular}

\footnotetext{
${ }^{10}$ There is no capital gain tax on listed stocks in Korea while $15.4 \%$ of tax is applied to the dividend income.

${ }^{11}$ Korea has undertaken interest liberalization as a part of economic reforms since the curly 1990s. The four-phase plan for interest rate liberalization was announced in 1991 and deposit rate liberalization was completed in 1995 during the third stage of the interest rate liberalization plan.
} 


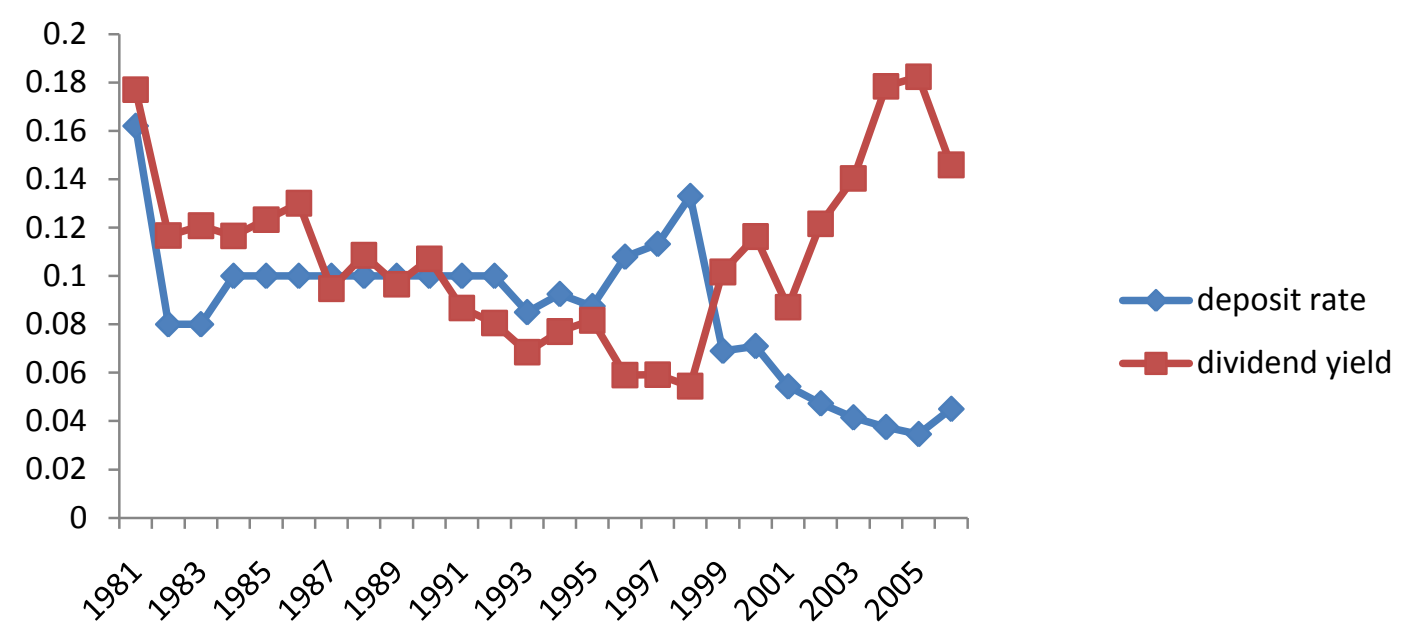

Figure 1: The Relationship between Deposit Rate and Dividend Payment Divided by Face Value

Table 3 contains correlation coefficients between the variables utilized in the multi-variate regressions. The dividend smoothing measure, $\mathrm{C}_{\mathrm{i}}$, evidences significant correlation coefficients with SIZE, HISTORY, RISK, and GROWTH. It is apparent that some independent variables are correlated highly with each other. SLACK is negatively correlated with SIZE, a finding which is consistent with the pecking order hypothesis of Myers and Majluf (1984). HISTORY has significant correlation coefficients with the majority of other independent variables in equation (2), with the exception of SLACK. The potential for multi-collinearity suggests that the re-estimation of variations of Eq. (2) with only uncorrelated independent variables may be needed.

Table 3: Pair-Wise Correlation Between Variables

\begin{tabular}{|l|c|c|c|c|c|c|c|}
\hline & $\mathbf{C}_{\mathbf{i}}$ & SIZE & OWN & HISTORY & SLACK & RISK & GROWTH \\
\hline $\mathrm{C}_{\mathrm{i}}$ & 1.0000 & & & & & & \\
\hline SIZE & -0.2653 & 1.0000 & & & & & \\
\hline & $(<.0001)$ & & & & & & \\
\hline OWN & -0.0267 & -0.1447 & 1.0000 & & & & \\
\hline & $(0.6477)$ & $(0.0127)$ & & & & & \\
\hline HISTORY & -0.3180 & 0.2523 & -0.0663 & 1.0000 & & & \\
\hline & $(<.0001)$ & $(<.0001)$ & $(0.2557)$ & & & & \\
\hline SLACK & 0.0665 & -0.3894 & 0.3424 & 0.0431 & 1.0000 & & \\
\hline & $(0.2541)$ & $(<.0001)$ & $(<.0001)$ & $(0.4598)$ & & & \\
\hline RISK & -0.1776 & 0.1130 & 0.1306 & 0.2048 & 0.2519 & 1.0000 & \\
\hline & $(0.0022)$ & $(0.0521)$ & $(0.0246)$ & $(0.0004)$ & $(<.0001)$ & & \\
\hline GROWTH & -0.1248 & 0.4919 & -0.0863 & -0.1097 & -0.2129 & 0.0062 & 1.0000 \\
\hline & $(0.0318)$ & $(<.0001)$ & $(0.1385)$ & $(0.0595)$ & $(0.0002)$ & $(0.9153)$ & \\
\hline
\end{tabular}

* Firm size (SIZE) is estimated by the natural logarithm of total assets, growth rate (GROWTH) is the average growth rate of size over a minimum of 15 years prior to 2006 and a maximum of the twenty six years, financial slack (SLACK) is the ratio of accumulated retained earnings to total assets, and earnings variability (RISK) is measured using the standard deviation of earnings per share over a minimum of 15 years prior to 2006 and a maximum of the twenty-six years. Listing years (HISTORY) is measured by the number of years listed during the sample period. The percentage of the stock held by the largest shareholders $(\mathrm{OWN})$ is used as a proxy for the concentration of controlling shareholders. $\mathrm{C}_{\mathrm{i}}$ is measured by the speed of adjustment in equation (1). P-values are contained in parentheses.

We test the relationship between the firm characteristics and the firm's dividend smoothing pattern using a multivariate regression analysis. Table 4 depicts the results for a multivariate regression for the complete sample of dividend smoothing firms. 
Table 4: Multivariate Regressions Of Smoothing Factor On Firm-Specific Variables*

\begin{tabular}{|l|c|c|c|c|}
\hline & \multicolumn{2}{|c|}{ Model 1 } & \multicolumn{2}{c|}{ Model 2 } \\
\hline Variable & Estimate & P-Value & Estimate & $<.0001$ \\
\hline Intercept & 1.5603 & $<.0001$ & 1.7156 & 0.0007 \\
\hline SIZE & -0.0252 & 0.0773 & -0.0367 & $<.0001$ \\
\hline OWN & -0.0015 & 0.1954 & & \\
\hline HISTORY & -0.0183 & $<.0001$ & -0.01627 & 0.0582 \\
\hline SLACK & 0.1887 & 0.2765 & & \\
\hline RISK & -0.0060 & 0.0492 & -0.00531 & \\
\hline GROWTH & -0.2099 & 0.1855 & & \\
\hline
\end{tabular}

*Regressions of smoothing factor on firm-specific variables are reported. Computation of the smoothing factor is described in Table 1. P-values are contained in parentheses. Firm size (SIZE) is estimated by the natural logarithm of total assets, growth rate (GROWTH) is the average growth rate of size over a minimum of 15 years prior to 2006 and a maximum of the twenty six years, financial slack (SLACK) is the ratio of accumulated retained earnings to total assets, and earnings variability (RISK) is measured using the standard deviation of earnings per share over a minimum of 15 years prior to 2006 and a maximum of the twenty-six years. Listing years (HISTORY) is measured by the number of years listed during the sample period. The percentage of the stock held by the largest shareholders $(\mathrm{OWN})$ is used as a proxy for the concentration of controlling shareholders. Smoothing factor is measured by $C_{i}$, the speed of adjustment in equation (1).

Model 1 is estimated using all the variables in the equation (1), whereas Model 2 is the re-estimation of Model 1 using a stepwise regression technique to minimize the problem of multi-collinearity. The results in Model 1 demonstrate that firm's size and listing years have significantly negative coefficients, suggesting that larger and older firms are more likely to smooth dividends. The result is not consistent with the theoretical predictions suggested by the signalling theory of dividends. Signaling theory indicates that smaller and younger firms have a greater incentive to smooth dividends since the information revealed with dividend changes is significantly high for these firms (Ghosh and Woolridge (1988), and Dewenter and Warher (1998)). However, the results for Korean firms provide the opposite evidence. It appears that the dividend smoothing hypothesis based on the signaling theory is not supported in the case of Korea. Risk has a negative sign, thereby indicating that riskier firms tend to pay more smoothed dividends. The result is consistent with the prediction made by Kumar (1988). Kumar predicted that firms in the risky industries are more likely to smooth dividends in order to develop a reputation for having a low systematic risk. GROWTH, OWN, and SLACK show insignificant coefficients, suggesting that other theories of dividend smoothing including the agency theory do not explain the dividend smoothing patterns in Korea. The results from the re-estimation of Model 1 that drop correlated variables from the regression are also consistent with the findings for the full model.

\section{CONCLUSIONS}

This study evaluates the dividend policies of Korean firms. The research described herein focused on investigating the manner in which Korean firms establish their dynamic dividend policies in a different institutional environment than that of developed markets, such as the US. In particular, this study attempted to empirically determine whether Korean firms follow stable dividend policies as in developed markets where dividend smoothing is a stylized fact. The paper also identified firm-level factors that influence the degree of dividend smoothing. For this purpose, 299 firms listed on the Korea Stock Exchange over the 26-year period (1980 to 2006) were investigated.

The empirical results presented in this study demonstrate that the majority of Korean firms pay smoothed dividends. However, the speed of adjustment to the target payout ratio is more rapid than in the developed market, thereby implying a lesser degree of dividend smoothing. The average speed of adjustment is $68 \%$ and the Lintner model explains $52 \%$ of the dividend changes of Korean firms. As compared with the US, Korean dividend behavior is explained less by the Lintner model and Korean firms pay smoothed dividends to a lesser degree. A change in dividend payments is less likely to reflect a change in the fundamentals of the company. Rather, it is closely associated with the interest rates of one-year time deposits. These results also indicate that dividend decisions in Korea are not predicated on long-term target payouts, as was hypothesized originally by Lintner (1956). This view is 
supported by the implicit payout ratios, which deviate substantially from the observed payout ratios. The long-term target ratio is $18.3 \%$, and is significantly lower than the observed payout ratio. The average observed payout ratio for Korean firms is also lower than that of US firms. This result may be attributable to the unfavorable tax treatment of dividend income in Korea.

For the determinants of dividend smoothing, company risk, size, and listing year perform crucial functions in the empirical explanation of the cross-section of dividend smoothing behavior. However, the relationships between these explanatory variables and the degree of dividend smoothing are systematically different between firms in the US and Korea. Contrary to the theoretical predictions, our empirical findings demonstrate that the larger and older firms are more likely to smooth dividends. Financial slack, growth, and ownership structure exert insignificant effects on the degree of dividend smoothing. These results indicate that information and agency theories do not explain the dynamic dividend behavior of Korean firms. Our results also show that riskier firms tend to pay more smoothed dividends, which supports the prediction made by Kumar (1988).

\section{AUTHOR INFORMATION}

Jinho Jeong is Professor of Finance at Korea University. He has been Policy Adviser to Free Economic Zone Authority in Korea, Director of Korea Finance Association, Director of Korea Industrial Economics Association, and Associate Editor of Journal of Korean Finance Study. Currently, he is Vice President of Korea Finance Association, Director of International Association of Area Studies, and Managing Director of Korea Securities Association. Professor Jeong received his Ph.D. from Georgia State University (1991). He has taught at University of Otago and Kyungnam University. His research interests and publications are in the areas of dividend policy, financing behavior, market integration, and market efficiency. Professor Jeong has published more than fifty articles in finance journals.

\section{REFERENCES}

1. Aivazian, V., L. Booth and S. Cleary. Dividend Policy in Developing Countries, Journal of Multinational Financial Management, volume 13, 2003, pp. 101- 121.

2. Allen, F. and Michaely, R. Payout Policy, North-Holland Handbook of Economics, edited by George Constantinides, Milton Harris and Rene Stulz, 2003, pp. 337-429

3. Bhattacharya, S. Imperfect Information, Dividend Policy and The Bird in the Hand Fallacy, The Bell Journal of Economics, volume10, 1979, pp. 259-270.

4. Bernheim, D. Tax Policy and the Dividend Puzzle, The RAND Journal of Economics, volume 22, 1991, pp. 455-476.

5. Billings, B. Is earnings variability related to future stock returns?, Florida State University working paper, 1999.

6. Brav, A., Graham, J.R., Harvey, C.R. and Michaely, R. Payout policy in the 21st century, Journal of Financial Economics, volume 77, 2005, pp. 483-527.

7. Chaney, P.K. and Lewis, C.M. Earnings management and firm valuation under asymmetric information, Journal of Corporate Finance, volume 1, 1995, pp. 319-345.

8. Dewenter and Warther. Dividends, Asymmetric Information and Agency Conflicts: Evidence from a comparison of the Dividend Policies of Japanese and U.S. Firms, Journal of Finance, volume 53, 1998, pp. 879-904.

9. Eddy, A. and Seifert, B. Firm size and dividend announcements, Journal of Financial Research, volume 11, 1998, pp. 295-302.

10. Fama, E.F. and Babiak, H. Dividend Policy: An empirical analysis, Journal of American Statistical Association, volume 63, 1968, pp. 1132-1161.

11. Freeman, R. The association between accounting earnings and security returns for large and small firms, Journal of Accounting and Economics, volume 9, 1987, pp. 195-228.

12. Garrett, I. and Priestley, R. Dividend behaviour and dividend signalling, The Journal of Financial and Quantitative Analysis, volume 35, 2000, pp. 173-189.

13. Ghosh, C. and Woolridge, J.R. An analysis of shareholder reaction to dividend cuts and omissions, Journal of Financial Research, volume 11, 1988, pp. 281-294. 
14. Gomes, A. Going Public without Governance: Managerial Reputation Effect, Journal of Finance, volume 55(2) number 4, 2000, pp. 615-646.

15. Grullon, G., Michaely, R. and Swaminathan B. Are Dividend Changes a Sign of Firm Maturity?, The Journal of Business, volume 75, number 3, 2002, pp. 387-424.

16. Harvie, C. and Lee, H. New Regionalism in East Asia: How Does It Relates to the East Asian Economic Development Model, ASEAN Economic Bulletin, volume 19, number 2, August 2002.

17. John, K. and Williams, J. Dividends, dilution and taxes: A signalling equilibrium, Journal of Finance, volume 40, 1985, pp. 1053-1070.

18. Kross, W. and Schroeder, D.A. Firm prominence and the differential information content of quarterly earnings announcements, Journal of Business, Finance and Accounting, volume 16, 1988, pp. 55-74.

19. Kumar, P. Shareholder-manager conflict and the information content of dividend, Review of Financial Studies, volume 1, 1988, pp. 111-136.

20. Kumar, P. and Lee, B. Discrete Dividend Policy with Permanent Earnings, Financial Management, volume 30, 2001, pp. 55-76.

21. Laub, M. On the informational content of dividends, Journal of Business, volume 49, 1976, pp. 73-80.

22. La Porta, R., Lopez-de-Silanes, F. and Shleifer, A. Corporate ownership around the World, Journal of Finance, volume 55, 2000, pp. 1-33.

23. Lee, C., Wu, C., and Djarraya, M. A further empirical investigation of the dividend adjustment process, Journal of Econometrics, volume 35, 1987, pp. 267-285.

24. Lintner, J.H. Distribution of incomes of corporations among dividends, retained earnings and taxes, American Economic Review, volume 46, 1956, pp. 97-113.

25. Marsh, T.A. and Merton, R.C. Dividend variability and variance bounds tests for the rationality of stock market prices, American Economic Review, volume 76, 1987, pp. 483-503.

26. Michaelly, R. and Roberts, M. Dividend smoothing, Agency Cost and Information Asymmetry: Lessons from Dividend Policies of Private firms, Cornell University Working paper, 2006.

27. Michaely, R., Thaler, R.H. and Womack, K.L. Price Reactions to Dividend Initiations and Omissions: Overreaction or Drift? The Journal of Finance, volume 50, number 2, 1995, pp. 573-608.

28. Myers, S.C. and Majluf N.S. Corporate Finance and Investment Decisions when Firms have Information that Investors Do Not Have, Journal of Financial Economics, volume 13, 1984, pp. 187-221.

29. Ronen, J. and Sadan, S. Smoothing income numbers: Objectives, means and implications, Readings, MA, Addison-Wesley, 1981.

30. Rozycki, J.J. A tax motivation for smoothing dividends, The Quarterly Review of Economics and Finance, volume 37, number 2, 1997, pp. 563-78. 


\section{NOTES}

